\title{
INTERAKSI MANUSIA DAN LINGKUNGAN DALAM NOVEL BILANGAN FU KARYA AYU UTAMI (KAJIAN EKOKRITIK GREG GARRARD
}

\section{HUMAN AND ENVIRONMENTAL INTERACTIONS BILANGAN FU NOVEL WRITTEN BY AYU UTAMI (GREG GARRARD'S ECOCRITICISM STUDY)}

\author{
Dewi Susilowati ${ }^{1}$, Ngatma'in ${ }^{2 *}$, Ali Nuke Affandy ${ }^{3}$ \\ Bahasa Inggris, SMP Hidayatul Ummah Surabaya, Indonesia ${ }^{1}$ \\ Pendidikaan Bahasa dan Sastra Indonesia, Universitas Muhammadiyah Surabaya, \\ Indonesia $\mathrm{a}^{2,3}$ \\ bundamelfin@gmail.com ${ }^{1}$, dirjopenewu@gmail.com ${ }^{2}$, alinukeaffandy @yahoo.com $^{3}$ \\ *penulis korespondensi
}

\begin{tabular}{ll}
\hline Info Artikel & ABSTRAK \\
\hline Sejarah artikel: & Interaksi manusia dan lingkungan dapat berlangsung secara harmonis. \\
Diterima: & Apabila manusia mampu mengelola lingkungan secara baik, lingkungan \\
7 Agustus 2021 & akan memberikan imbal baik positif bagi manusia. Namun jika manusia \\
Direvisi: & tidak mampu berinteraksi dengan alam secara baik, lingkungan akan \\
3 Desember 2021 & menunjukkan sikap yang kurang bersahabat. Fokus penelitian ini adalah \\
Disetujui: & interaksi manusia dan lingkungan dalam novel Bilangan Fu karya Ayu \\
10 Januari 2022 & Utami berdasarkan konsep ekokritik Greg Garrard. Tujuan penelitian adalah \\
& untuk mendeskripsikan interaksi manusia dan lingkungan dalam novel \\
Kata kunci: & Bilangan Fu karya Ayu Utami berdasarkan konsep ekokritik Greg Garrard. \\
ekokritik, greg garrard, & Metode penelitian menggunakan close reading. Sumber data penelitian \\
interaksi manusia dan & adalah novel Bilangan Fu karya Ayu Utami. Hasil penelitian menunjukkan \\
lingkungan & bahwa interaksi manusia dan lingkungan dalam novel Bilangan Fu karya \\
& Ayu Utami dicirikan dengan beberapa hal, yaitu: adanya pencemaran udara, \\
& perusakan hutan, pemunculan tanda bencana, perusakan habitat, pemburuan \\
& binatang, dan eksploitasi bumi.
\end{tabular}

\begin{tabular}{|c|c|}
\hline Article Info & ABSTRACT \\
\hline Article history: & Human and environmental interactions can take place in harmony. If \\
\hline Received: & humans are able to manage the environment well, the environment makes a \\
\hline 7 August 2021 & positive contribution to humans. However, if humans do not interact with \\
\hline Revised: & the nature properly, the environment will show a less friendly attitude. The \\
\hline 3 December 2021 & focus of the research is the interaction of humans and the environment in the \\
\hline Accepted: & novel Bilangan $F u$ by Ayu Utami based on Greg Garrard's ecocriticism. The \\
\hline 10 January 2022 & $\begin{array}{l}\text { purpose of this research is to describe the interaction of humans and the } \\
\text { environment in the novel Bilangan } F u \text { written by Ayu Utami based on Greg }\end{array}$ \\
\hline Keyword: & Garrard's ecocriticism concept. The research method used close reading. \\
\hline ecocritic, $g r$ & The research data source is the novel Bilangan Fu written by Ayu Utami. \\
\hline human and & The result of the study indicate that the interaction bertween humans and the \\
\hline environmental & environment in the novel Bilangan $F u$ written by Ayu Utami is \\
\hline interactions & $\begin{array}{l}\text { characterized by several things, namely: air pollution, forest destruction and } \\
\text { the appearance of disaster signs, habitat destruction, animals hunting, and } \\
\text { earth exploitation. }\end{array}$ \\
\hline
\end{tabular}




\section{PENDAHULUAN}

Interaksi manusia dan lingkungan dapat berlangsung secara harmonis apabila manusia mampu memahami posisinya di dalam ekosistem dunia dan mampu mengelola lingkungan secara baik, lingkungan akan memberikan kontribusi positif kepada manusia. Namun jika manusia tidak mampu mengemban amanah, lingkungan akan menunjukkan sikap yang kurang bersahabat. Beragam aktivitas manusia yang tidak baik bagi lingkungan antara lain: pencemaran udara, perusakan hutan, perusakan habitat, ekploitasi, dan lain-lain.

Hendaknya manusia tidak melakukan aktivitas-aktivitas yang merugikan lingkungan karena manusia juga memiliki peran yang sama dengan lingkungan yaitu sebagai mahluk biologis dan ekologis yang memiliki tugas menjaga lingkungan sebagai salah satu tempat berkembang dan menjalankan perintah tuhan.

Manusia dan lingkungan saling ketergantungan. Lingkungan sebagai sarana kelangsungan hidup manusia. Lingkungan juga membutuhkan kasih sayang manusia demi terciptanya ekosistem yang harmonis. Namun hubungan tersebut bisa saja berubah dan tidak sesuai dengan keinginan kedua belah pihaka manakala manusia dan alam tidak melakukan interaksi positif. Manusia tidak lagi menyayangi lingkungan, sebaliknya lingkungan tidak bersahabat dengan manusia.

Interaksi yang tidak harmonis antara manusia dan lingkungan dapat terjadi apabila keduanya tidak saling memberi keuntungan. Ketidakselarasan tersebut bisa jadi dipengaruhi oleh dominasi salah satu pihak atau memang kedua belah pihak sama-sama ingin menguasai pihak yang lain. Manusia ingin menguasai lingkungan dengan sesuka hati dengan cara menggali seluruh potensi demi kesenangan, keuntungan, dan kelangsungan hidup yang dapat merusak lingkungan. Pada sisi yang lain, lingkungan juga terkadang kurang bersahabat dengan manusia. Lingkungan kurang bersedia berdampingan dengan manusia. Ia senantiasa melakukan aksi-aksi yang kurang baik baik manusia, misalnya mengeluarkan lava, suhu ekstrem, gempa, angin puyuh, atau menumpahkan air yang berlebih.

Pada awal tahun 2021, terjadi bencana ekologi yang menerjang provinsi Kalimantan Selatan. Sebagaimana yang dilaporkan oleh Yahya pada Kompas.com bahwa di kawasan tersebut terjadi banjir besar yang disebabkan oleh curah hujan ekstrem dan banyaknya pembukaan lahan untuk perkebunan dan pertambangan. Kini banyak hutan lindung di Jawa dan Luar Jawa yang berubah menjadi perkebunan monokultur sawit dan tambang batu bara. Perluasan lahan secara terusmenerus inilah yang menjadi salah satu penyebab bencana banjir terutama di kondisi cuaca ekstrem. Banjir menyebabkan banyak masalah, diantaranya: sekitar 63 ribu orang mengungsi, 21 orang korban jiwa, dan 342 ribu orang terdampak. Banjir juga menyebabkan ribuan hektar lahan pertanian gagal panen. Tak hanya itu, banyak rumah terendam, ribuan meter jalan terendam, dan puluhan jembatan rusak (Yahya: 2021).

Fenomena lain terjadi pada hari Senin, 15 Juni 2020, ditemukan aktivitas penebangan liar di daerah cagar alam Bukit Bungkuk di Kabupaten Kampar Riau. Para pembalak hanya memperhitungkan daya jual kayu yang dihasilkan tanpa memikirkan apa yang terjadi apabila 
hutan kita rusak. Pembalakan secara liar akan mengakibatkan berbagai masalah, seperti; berkurangnya sumber daya air, hilangnya kesuburan tanah dan punahnya keanekaragaman hayati. Kerusakan hutan bisa mempengaruhi perubahan keanekaragaman hayati dan pola perubahan iklim (Tanjung: 2020). Wismabrata (2020) juga menulis bahwa pada bulan Oktober 2020 akibat kerusakan hutan di Kecamatan Cikajang dan Cisompet, menyebabkan banjir bandang dan longsor yang melanda wilayah Garut, Jawa Barat. Akibat peristiwa ini beberapa desa terendam banjir. Seharusnya masyarakat melakukan penebangan secara konservatif yaitu penebangan pada pohon yang tidak produktif lagi.

Adanya bulan tiruan di kota Chengdu China juga telah menjadi berita yang fenomenal saat itu. Fenomena ini terjadi akibat dari egoisme manusia yang berusaha mengubah dunia sesuai kehendak manusia itu sendiri. Bulan tiruan diluncurkan dengan alasan untuk menghemat biaya listrik sampai 2,5 Triliun dan bisa dimanfaatkan untuk membantu tim SAR apabila terjadi listrik mati atau bencana. Tapi bagaimana dengan polusi cahaya yang diakibatkan oleh bulan tiruan ini? Apakah kesehatan masyarakat kota Chengdu juga sudah dikaji? Dan bagaimana populasi hewan dan tumbuhan (Hananto: 2019).

Bilangan $F u$ karya Ayu Utami menjadi media pembelajaran ekokritik sastra. Bilangan $F u$ menyajikan interaksi manusia dan lingkungan. Gambaran yang berkaitan dengan penguasaan, pemanfaatan, dan pelestarian lingkungan. Interaksi manusia dan lingkungan digambarkan sebagai berikut.

\section{Penjarahan hutan jati di Sewugunung menyebabkan ketigabelas mata air disana menjadi keruh dan surut (Utami, 2019: 634).}

Banyaknya kegiatan penjarahan hutan jati yang mengakibatkan sumber air di Sewugunung menjadi berkurang. Jika kondisi semacam ini dibiarkan maka masalah senantiasa berkembang. Banyak perselisihan antar warga masyarakat karena saling berebut air bersih. Jika air bersih sulit didapatkan kesehatan masyarakat dapat terganggu.

Dalam perbincangan para kritikus sastra, hubungan antara manusia, alam dan sastra memunculkan sebuah persepsi baru tentang sebuah perselingkuhan kreatif yang estetis. Manusia sebagai objek sastra dan alam sebagai pijakan sastra. Sedangkan sastra adalah hasil karya manusia (Endraswara, 2016). Hingga lahirlah sebuah konsep kritik sastra baru yaitu ekokritik (ecocriticism). Ekokritik adalah sebuah paham yang membahas tentang karya sastra yang berhubungan dengan manusia, alam dan budaya. Menurut Garrard (dalam Endraswara, 2016) ekokritik sastra adalah studi mengenai gambaran hubungan antara manusia dan lingkungan dalam segala bidang hasil budaya.

Ekologi adalah ilmu yang mempelajari sesuatu yang terkandung dalam alam tanpa memberikan percobaan tertentu (Irwan, 2018). Ekologi merupakan kajian ilmiah tentang hubungan antarorganisme terhadap lingkungannya. Sedangkan kritik dapat diartikan sebagai bentuk ekspresi dan penilaian terhadap kualitas sesuatu. Secara sederhana ekokritik adalah sebuah kritik yang berwawasan lingkungan. 
Selanjutnya Juanda (2018) menjelaskan bahwa Ecocriticism menunjukan karya kritis yang mengeksplorasi interaksi antara sastra dan lingkungan fisik dan biologis. Ecocriticisme merupakan kajian sastra yang mempelajari tentang interaksi antara manusia dan nonmanusia, nilai sejarah manusia dan kultur yang terkait dengan analisis kritis manusia dan lingkungannya. Coupe (dalam Juanda, 2018) telah memaparkan bahwa ekokrotisisme adalah ilmu yang interdisipliner.

Dalam sejarah ilmu sastra, ekokritik merupakan jenis kritik sastra baru yang diciptakan oleh William Rueckert pada tahun 1978 dalam esainya "Literature and Ecology: An Experiment in Ecocriticism". Kajian tentang sastra hijau berawal pada tahun 1990-an. Ekokritisisme muncul sebagai disiplin yang dapat dikenal dalam departemen sastra beberapa universitas di Amerika. Hal ini sesuai dengan pemaparan Garrard (2004) sebagai berikut.

Garrard (dalam Endraswara, 2016) mengungkapkan bahwa ekokritik adalah ilmu yang menganalisis sastra dari sudut pandang lingkungan. Tinjauan teori ini bertujuan untuk mengamati krisis yang terjadi pada lingkungan yang tidak hanya menimbulkan beberapa pertanyaan teknis, ilmiah dan politik, tetapi juga persoalan budaya yang terkait dengan fenomena sastra. Ekokritik lahir karena kondisi alam yang semakin tua dan rusak sehingga membutuhkan perhatian manusia. Ketidakseimbangan alam menimbulkan berbagai polemik di kehidupan manusia dan akhirnya memunculkan persoalan baru baik yang berhubungan dengan politik, sosial maupun budaya. Beberapa masalah itu memunculkan rasa kepedulian untuk mengatasi permasalahan tersebut demi kehidupan berikutnya.

Ekokritik adalah gabungan dua teori antara teori sastra dan teori budaya yang memiliki hubungan dengan ilmu ekologi. Ekokritik mungkin tidak memenuhi syarat untuk berkontribusi pada perdebatan tentang masalah dalam ekologi, tetapi mereka harus melampaui batas disiplin dan mengembangkan 'literasi ekologi' mereka sendiri sejauh mungkin. Oleh karena itu perlu diberikan pembahasan secara singkat tentang beberapa ancaman lingkungan penting yang dihadapi oleh dunia saat ini (Garrand, 2004).

Kajian ekokritik ini dipilih karena beberapa pertimbangan. Pertama, cerita yang tersaji merupakan gambaran interaksi manusia dan lingkungan. Dalam novel ini Sewugunung dan sekitarnya menjadi latar cerita. Kedua, kerusakan alam yang ada dalam novel Bilangan $F u$ bukan hanya disebabkan penambangan kapur dan kerusakan tebing semata, melainkan kurangnya kesadaran manusia terhadap lingkungan di Sewugunung. Ketiga, masyarakat yang dihadirkan pada novel Bilangan $F u$ merupakan masyarakat yang dekat dengan alam. Yang terakhir, polemik yang terjadi antara manusia dan lingkungan di Sewugunung dalam novel Bilangan $F u$ merupakan salah satu bentuk kritik kesusastraan ekologi Indonesia. Fokus penelitian ini adalah interaksi manusia dan lingkungan dalam novel Bilangan $F u$ karya Ayu Utami berdasarkan konsep ekokritik Greg Garrard. Tujuan penelitian adalah untuk mendeskripsikan interaksi manusia dan lingkungan dalam novel Bilangan $F u$ karya Ayu Utami berdasarkan konsep ekokritik Greg Garrard. 


\section{METODE}

Metode penelitian yang digunakan adalah close reading. Teks dicermati secara mendalam sehingga lapisan makna dapat diungkap. Close reading adalah penafsiran secara menyeluruh dari suatu teks dengan menentukan tema utama dan menganalisis perkembangannya (Janicke dkk dalam Nugraha \& Suyitno, 2019).

Beberapa tahapan yang digunakan dalam penelitian antara lain: 1) pembacaan teks, 2) penandaan pada teks yang spesifik, unik, diksi, pola tertentu, dan penyimpangan, kata atau bagian dari teks yang relevan dengan tema tertentu, 3) pembacaan ulang teks secara cermat, pelan, dan kritis, 4) penafsiran, dan 5) penarikan simpulan (Nugraha \& Suyitno, 2021).

Data penelitian adalah satuansatuan bahasa yang terdapat dalam novel Bilangan $F u$ karya Ayu Utami. Novel Bilangan Fu karya Ayu Utami menjadi sumber data penelitian yang diterbitkan oleh Gramedia dan dicetak ulang tahun 2019.

\section{HASIL DAN PEMBAHASAN}

Lingkungan dipandang sebagai alat pemenuhan kebutuhan dan objek eksploitasi sistem kapitalis ekonomi. Penguasaan manusia terhadap lingkungan semakin mengakar menyebabkan kerusakan yang sangat berarti. Apabila kondisi tersebut tidak diimbangi dengan tindakan preventif dan represif, lingkungan akan mengalami kehancuran yang sangat berarti. Ketidaksadaran manusia terhadap lingkungan dapat menimbulkan berbagai masalah yang berkepanjangan. Masalah akan terjadi sepanjang manusia menjalankan semua peranannya di dalam kehidupan. Selama manusia masih menggantungkan hidupnya terhadap lingkungan, selama itu pula masalah terus terjadi.

Masalah dapat terjadi akibat munculnya kesenjangan ekosistem lingkungan dengan kebutuhan manusia. Munculnya kesenjangan dapat digambarkan melalui berbagai faktor, antara lain adanya pencemaran udara, perusakan hutan, pemunculan tanda bencana, perusakan habitat, pemburuan binatang, dan eksploitasi bumi.

\section{Pencemaran Udara}

Pencemaran udara menjadi masalah bagi manusia. Masalah muncul karena manusia tidak lagi mendapatkan udara yang sehat. Udara yang mereka hirup senantiasa tercemar berbagai polusi yang berasal dari asap kendaraan, polusi pabrik, limbah rumah tangga, limbah indutri dan lain-lain. Pada sisi yang lain, pencemaran dipengaruhi oleh aktivitas manusia yang tidak memperhatikan lingkungan dan berdampak pada pemanasan global.

Pemanasan global merupakan kenaikan suhu rata-rata yang terjadi pada bumi. Kondisi ini memerlukan penanganan yang serius baik dalam mencegah, mengurangi, maupun mengatasi efek negatif dari pemanasan Global. Pemanasan global terjadi dikarenakan oleh penggunaan bahan bakar fosil, gas emisi yang berasal dari asap kendaraan dan pabrik, dan timbulnya senyawa-senyawa yang bersifat organik, misalnya clorofluorocarbon.

Berbagai cara dapat dilakukan agar pemanasan global dapat berkurang. Cara-cara yang dapat dilakukan adalah pengurangan penggunaan bahan bakar fosil, penggunaan energi alternatif, pelestarian hutan, penghijauan, penghematan listrik, penggunaan kertas 
secara bijak, dan pelaksanaan kegiatan reduce, reuse dan recycle.

Novel Bilangan $F u$ karya Ayu Utami menyajikan berbagai persoalan yang berkaitan dengan isu-isu lingkungan sebagai dampak kemajuan ilmu pengetahuan. Isu lingkungan ini telah menjadi kekhawatiran masyarakat secara mendunia, dan mereka juga berlomba-lomba mencari solusinya. Gambaran kondisi tersebut disajikan dalam kutipan berikut.

Mbok Manyar mengajak kami menyadari betapa air telah keruh dan mulai surut. Ada nada marah pada suaranya, meski ia tidak mengeluhkan siapa pun. Parang Jati menjelaskan kepadaku bahwa belakangan ini beberapa sendang desa tak lagi jernih. (BF/KI/KEP/Utami, 2019: 153)

Kualitas air yang berada di beberapa sendang di Sewugunung mulai berubah warna. Bahkan kolam yang ada di sana juga mengering sebelum puncak kemarau. Selain itu, penyebab keruhnya air juga disebabkan oleh pencemaran udara yang dapat mengganggu kehidupan masyarakat. Air merupakan pelarut universal dan mempunyai sifat yang rentan akan polusi. Oleh karena itu, air merupakan cairan yang mampu melarutkan lebih banyak zat daripada cairan lainnya yang ada di bumi. Padahal untuk melanjutkan hidup, baik manusia mapun makhluk lainnya sangat membutuhkan air bersih. Oleh karena itu, manusia hendaknya mulai berpikir untuk tidak selalu bergantung dengan bahan bakar yang bisa menimbulkan pencemaran udara.

Untuk menjaga kelestarian lingkungan dan perlakuan masyarakat terhadap lingkungan dibutuhkan peraturan yang mengatur tentang perlindungan dan pengelolaan terhadap lingkungan hidup. Perlindungan tersebut telah diatur oleh pemerintah dalam Undang-Undang Nomor 32 tahun 2009 Tentang Perlindungan dan Pengelolaan Lingkungan Hidup (UUPPLH). Pasal 1 angka (2) disebutkan bahwa perlindungan dan pengelolaan lingkungan hidup adalah upaya sistematis dan terpadu yang dilakukan untuk melestarikan fungsi lingkungan hidup dan mencegah terjadinya pencemaran dan/atau kerusakan lingkungan hidup yang meliputi perencanaan, pemanfaatan, pengendalian, pemeliharaan, pengawasan, dan penegakan hukum. Lebih lanjut disebutkan pada pasal 1 angka (6) bahwa pelestarian fungsi lingkungan hidup adalah rangkaian upaya untuk memelihara kelangsungan daya dukung dan daya tampung lingkungan hidup.

Rachmad (dalam Nurkamilah, 2018) berpendapat bahwa etika biosentrisme memiliki pandangan bahwa setiap kehidupan dan makhluk hidup mempunyai nilai intrinsik pada dirinya sendiri. Hal senada juga uraikan Keraf (2010) bahwa biosentrisme adalah pandangan yang menganggap manusia dan alam sama-sama memiliki nilai. Ciri utama teori ini adalah biocentric yang berarti semua kehidupan dan makhluk hidup memiliki nilai. Karena masing-masing elemen tersebut bernilai jadi pantaslah setiap elemen tersebut mendapatkan perhatian dan kepedulian moral.

\section{Perusakan Hutan}

Perusakan hutan dapat memicu timbulnya masalah. Jika hutan rusak, semua ekosisten di dalamnya juga akan mengalami masalah serius. Manusia yang selalu menggantungkan hidupnya 
kepada lingkungan akan merasakan dampak yang sangat besar. Jika hutan rusak, ketersediaan air, udara yang sehat, binatang, dan sumber kekayaan alam yang lain juga mengalami kerusakan.

Perusakan hutan adalah proses penurunan kualitas ekosistem hutan. Perusakan hutan dipicu oleh proses perambahan hutan, pembalakan liar, kebakaran, dan serangan hama dan penyakit. Pembalakan liar merupakan proses penebangan liar yang terjadi di kawasan hutan sehingga mengubah fungsi awal hutan. Kebakaran hutan dapat terjadi secara alami dan ulah manusia Kebakaran hutan dapat terjadi secara alami apabila kondisi suhu lingkungan sangat panas. Perambaan hutan dilakukan dalam rangka menambah jumlah lahan pertanian. Populasi hama yang tidak terkontrol dapat menyebabkan perusakan hutan.

Apabila terjaga dengan baik, hutan akan menyerap semua air hujan. Hutan juga dapat berfungsi sebagai pengontrol debit air sungai sehingga dapat mengatur fluktuasi air. Melalui kinerja hutan tersebut, air hujan tidak meluap dan tidak mengering saat musim kemarau. Ketika hutan tidak terawat dengan baik maka ekosistem juga ikut rusak. Dampak yang dapat ditimbulkan akibat kerusakan hutan antara lain, perubahan iklim, kehilangan beragam spesies, terganggunya siklus air, banjir dan erosi, kekeringan, kerusakan ekosistem darat dan laut, abrasi, dan beragam dampak lain yang dapat mengurangi kualitas hidup manusia.

Perusakan hutan belantara yang disebabkan oleh perilaku manusia yang tidak menghargai alam dipresentasikan sebagai berikut.
Kami melaju ke Selatan, melewati garut, Rajapola, dengan pemandangan hijau biru gunung Galunggung, lalu turun ke tempat rendah yang silauterik, Tasik, тепијu Pangandaran. Lalu terus ke Timur. Melewati perkebunan karet yang beralur-alur rapi. Hutan-hutan jati yang berjambul ranggas. Ia selalu membaca buku dalam jeda-jeda percakapan. (BF/KI/KEHB/Utami, 2019: 40)

Hutan-hutan telah terlihat berjambul ranggas. Kondisi itu menandakan kalau pepohonan di hutan banyak yang telah dibakar oleh manusia sehingga mengakibatkan hutan menjadi kering dan tandus. Pohon-pohon hijau nan rindang dan rimbun yang awalnya menghiasi hutan bak permadani hijau, kini tinggal ranting-ranting kecokelatan tanpa daun. Fenomena membakar hutan dilakukan tanpa memikirkan dampak negatif yang akan terjadi. Dampak negatif yang akan ditimbulkan oleh fenomena ini banyak sekali, diantaranya; banjir, tanah longsor, kekeringan.

Selain pembakaran, perusakan hutan juga disebabkan oleh penebangan secara liar. Gambaran penebangan hutan tersaji dalam cuplikan berikut.

Belakangan aku mendengar bahwa ia mungkin sekali berada di belakang penebangan jati yang legal maupun ilegal di Sewugunung. (BF/KI/KEHB/Utami, 2019: 173)

Penebangan hutan secara liar tidak hanya dilakukan oleh masyarakat Sewugunung saja. Tapi beberapa oknum militer juga banyak yang berada di belakang bisnis gelap tersebut. 
Parang Jati tanpa team menemui berbagai kesulitan untuk menentang kekuasaan militer yang selain terus mengawasi semua kegiatan di hutan, juga mencari keuntungan dengan cara merusak alam tersebut. Bahkan masyarakat Sewugunung diteror dengan isu pembunuhan dukun santet untuk meningkatkan rasa ketakutan, kurang nyaman dan cemas bagi masyarakat. Isu tersebut dirancang dengan apik oleh militer untuk mendapatkan nilai simpati masyarakat. Teror terus berembus dan membuat masyarakat Sewugunung selalu dalam ketakutan. Di Suasana inilah militer hadir sebagai pahlawan untuk memberi rasa aman terhadap masyarakat.

Manusia senantiasa menjadi sumber pemicu masalah. Kondisi demikian karena manusia meyakini bahwa ia bertindak sebagai penguasa, pengguna, dan pemeriksa lingkungan. Manusia berprinsip bahwa segala sesuatu yang tersaji di alam merupakan anugerah yang difungsikan sebagai alat pemenuh kebutuhan. Manusia menjadi pusat dalam pengelolaan alam sebagaimana pendapat Lorens (dalam Fajriah, 2018) bahwa manusia menjadi pusat atas alam ini. Hal ini mengacu pada teori anthropocentric yang berarti keberadaan manusia adalah poros dari alam semesta. Alam semesta hanya akan diperhatikan dan dipuja hanya ketika alam mampu memenuhi semua kebutuhan dan kepentingan manusia.

\section{Pemunculan Tanda Bencana}

Bencana adalah kejadian alam yang disebabkan oleh dua faktor, manusia dan lingkungan dan menimbulkan ancaman bagi kehidupan masyarakat. Bencana dapat menimbulkan banyak masalah, seperti: hilangnya harta benda, korban jiwa, kerusakan lingkungan, serta dampak psikologis yang diderita masyarakat. Bencana merupakan fenomena alam yang terjadi karena serangkaian peristiwa yang disebabkan oleh alam, antara lain berupa banjir, gempa bumi, gunung meletus, tanah longsor, tsunami dan lain sebagainya.

Bencana alam datang tanpa diundang dan tanpa diprediksi. Namun terkadang ada pertanda khusus yang dimunculkan oleh alam sebelum bencana menerjang. Manusia yang tinggal di sebuah lingkungan rawan harus mengetahuinya tanda-tanda munculnya bencana. Tanda-tanda alam yang harus diketahui oleh masyarakat yang bertempat tinggal di kawasan rawan bencana antara lain: langit berwarna kehijauan, lautan yang surut dengan tiba-tiba, pergerakan hewan yang tidak wajar, bunyi gemuruh besar saat atau sesudah hujan, kematian ikan dan hewan lainnya secara massal, dan berbagai tanda lain yang muncul. Selain itu, bagi masyarakat yang tinggal di dekat gunung berapi harus senantiasa waspada. Dalam novel Bilangan $F u$ karya Ayu Utami, juga digambarkan tanda-tanda akan datangnya bencana sebagai berikut.

Asalkan diperlakukan dengan baik oleh warga manusia, Pelus akan menampakkan diri pada orang-orang yang dipilihnya dan memberi pertanda mengenai gempa, air bah, musim salah, bencana maupun pageblug yang sedang mendekati desa. (BF/KI/KEB/Utami, 2019: 151)

Masyarakat Sewugunung percaya adanya seekor ikan Pelus dapat memberikan tanda-tanda akan datangnya bencana. Masyarakat Sewugunung menganggap ikan Pelus merupakan ikan mitologis yang dapat 
menghubungkan para penduduk dengan leluhurnya. Ikan Pelus dijadikan sebagai ikan bertuah oleh penduduk Sewugunung, ikan yang jarang menampakkan diri kepada para penduduk. Penduduk menyakini bahwa ikan Pelus akan bermanfaat jika diperlakukan dengan baik. Ikan-ikan itu akan memberikan tanda kepada orang tertentu jika ada bencana yang akan datang. Hal ini yang menjadikan patokan bahwa masyarakat Sewugunung percaya bahwa Pelus adalah ikan keramat. Ikan ini memiliki kekuatan mendeteksi sesuatu yang buruk dan akan terjadi. Selain itu, tidak sembarang orang yang dapat menangkap tanda yang diberikan oleh ikan Pelus. Dalam novel Bilangan Fu seorang juru kunci dapat menangkap firasat yang diberikan ikan Pelus. Dia adalah Mbok Manyar, seorang juru kunci mata air desa.

Pemunculan tanda bencana harus dipahami oleh masyarakat secara bijak. Jika masyarakat kurang tepat dalam memaknai tanda bencana dapat memicu masalah. Bagi masyarakat tertentu, pemunculan tanda bencana harus masuk akal, bersifat alami, dan dan terbukti secara ilmiah. Sebaliknya, sebagian masyarakat juga meyakini bahwa tanda bencana dapat berasal dari sesuatu yang bersifat magis atau mistis. Jika masyarakat kurang arif dalam menyikapinya maka pemunculan tanda bencara tidak dapat ditangkap.

Apapun tanda bencana yang muncul karena memang dikehendaki tuhan. Sebagaimana konsep teosentrisme bahwa sesuatu yang terjadi di sekeliling manusia telah diskenario oleh tuhan. Manusia hanya mampu membuat rencana. Hal ini sebagaimana konsep teosentrisme yang disajikan oleh wordpress.com, 2017 (dalam Fajriah, 2018) bahwa sistem keyakinan dan nilai terkait ketuhanan secara moralitas lebih tinggi dibandingkan dengan sistem lainnya. Manusia tidak mempunyai kemampuan untuk melakukan aktivitasnya karena telah diatur oleh tuhan.

\section{Perusakan Habitat}

Tempat tinggal dapat didefinisikan sebagai sebuah tempat yang digunakan untuk berteduh, istirahat, berkembang, makan dan melakukan aktivitas lainnya bagi manusia atau hewan. Tempat tinggal dapat berbentuk rumah, sarang, sangkar, kandang, atau hutan. Hutan adalah salah satu tempat tinggal bagi satwa dari semut sampai gajah. Ketika hutan dirusak oleh manusia yang tidak bertanggung jawab, ancaman bagi satwa adalah hilangnya tempat tinggal mereka. Perampasan tempat tinggal bagi satwa berdampak pada hilangnya habitat alami satwa, hilangnya sumber makanan, terjadi kepunahan, dan berkurangnya keanekaragaman satwa dan flora.

Novel Bilangan $F u$ mempresentasikan dan mengulas tentang kerusakan alam. Kerusakan alam ini dilakukan oleh manusia dengan dalih semata-mata untuk memenuhi kebutuhan. Mereka tidak sadar apa yang dilakukan telah merusak habitat hewan sekaligus merampas tempat tinggal mereka. Gambaran perampasan tempat tinggal tersaji dalam cuplikan berikut.

... yang tak terjawab sampai hari ini. Yaitu, kenapa begitu banyak rumah polisi di negeri ini memiliki monyet diikat di pohon atau tiang? Komplek polisi, pos polisi, bahkan asrama polwan biasa dihiasi monyet di salah satu atau beberapa pojok 


\section{halamannya.}

(BF/KI/KED/Utami, 2019: 170)

Tindakan oknum yang telah memindahkan habitat monyet dari tempat asalnya merupakan bentuk perampasan tempat tinggal. Kegiatan tersebut berdampak kurang baik bagi satwa. Banyak aktivitas manusia yang dapat mengurangi kebebasan satwa, misalnya dengan memanfaatkan harimau, gajah, kuda, monyet atau satwa lain sebagai hewan penghibur dalam sebuah sirkus. Kegiatan tersebut dapat menyebabkan kematian satwa.

Banyak aktivitas manusia yang merugikan satwa, baik oleh kelompok atau individu. Aktivitas yang dilakukan oleh manusia berisiko pada perampasan tempat tinggal flora dan fauna. Banyak hutan berubah menjadi perkebunan. Pengambilan sarang burung kerap dilakukan. Pemindahan sarang lebah dari habitat alami ke habitat buatan. Kegiatan tersebut tentu sangat merugikan, beberapa satwa tidak lagi memiliki tempat tinggal yang layak untuk berteduh. Segala aktivitas manusia yang kurang menguntungkan lingkungan karena didasari pandangan bahwa semua yang tercipta di dunia ini dimanfaatkan untuk kepentingan manusia semata. Sebagaimana yang telah disampaikan Haskarlianus (dalam Yuono, 2019:) bahwa dunia diciptakan hanya untuk manusia dan bagi kepentingan manusia. Inilah yang menjadi penyebab terjadinya kerusakan habitat flora dan fauna oleh manusia.

\section{Perburuan Binatang}

Polusi air, tanah, dan udara dapat menjadi faktor penting yang menyebabkan kepunahan hewan. Akan tetapi manusia merupakan predator paling berbahaya bagi kelangsungan hidup binatang. Selain memanfaatkan sebagai salah satu sumber makanan, manusia juga mengeksploitasi hewan secara berlebih. Sikap konsumtif tidak dapat dihentikan karena jumlah populasi manusia semakin meningkat. Sikap konsumtif tersebut tentu mengandung persoalan serius bagi manusia dan lingkungan. Jika sumber protein berkurang, manusia akan menemui masalah.

Manusia mencari makanan dan energi pada alam seakan tidak pernah berhenti. Setiap saat, manusia mengeksploitasi sumber makanan dari lingkungan. Kondisi demikian menyebabkan luka yang sangat serius pada lingkungan. Populasi manusia terus meningkat sehingga pertumbuhan ekonomi global semakin naik. Untuk menyediakan sandang, pangan, dan energi, manusia membabat lingkungan secara masif. Hewan diburu secara liar tanpa adanya sikap alternatif untuk melestarikannya.

Hewan dimusnahkan tidak hanya untuk dikonsumsi tapi juga untuk dijadikan sebagai hiasan rumah. Kini, hal ini sedang berkembang dan menjadi gaya hidup masyarakat. Banyak species hewan langka yang dilindungi justru diperdagangkan secara ilegal. Bahkan hewan-hewan tersebut diperoleh dari dalam hutan-hutan tropis. Gambaran pemburuan binatang tersaji dalam kutipan berikut.

Temanku muncul dari balik tirai kerang lintingan kalender. Ia menyapaku dengan suara girang, matanya berbinar seperti melihat masa lalu yang jaya. (BF/KI/KEA/Utami, 2019: 33)

Pajangan rumah juga berdampak terhadap penghuni rumah. Pajangan berbentuk hewan tertentu dipercaya membawa keharmonisan dan 
keberuntungan dalam keluarga. Pernyataan tersebut menumbuhkan keinginan manusia untuk menjadikan kulit, daging, kepala, tulang hewan sebagai pajangan rumah. Dari kulit kerang yang sudah tidak terpakai sampai gading gajah dan kepala banteng ataupun kulit harimau mulai diburu untuk perabotan pemanis rumah.

Selain berfungsi sebagai hiasan, bulu, kulit, gading, cula, tanduk, kuku atau bagian-bagian tertentu binatang juga dipercaya memberikan dampak magis bagi pemilik. Tidak jarang binatang dimusnakan sebagai bahan pendatang kekuatan, kepercayaan, atau pengasihan.

\section{Eksploitasi bumi}

Bumi adalah planet yang digunakan oleh seluruh makhluk hidup sebagai tempat tinggal. Tempat manusia dapat berkegiatan untuk memenuhi kebutuhan. Oleh karena itu manusia wajib melestarikan dan menjaga bumi agar tidak mengalami kerusakan. Rusaknya alam dapat dilihat dari beberapa fenomena, antara lain: berkurangnya sumber daya air, menurunya kualitas kesuburan tanah, meningkatnya polusi udara, rusaknya ekosistem, serta punahnya tumbuhan dan hewan liar. Perusakan alam dapat disebabkan oleh peristiwa alam, misalnya gempa, angin puting beliung, meletusnya gunung berapi, tsunami, dan lain sebagainya. Selain itu, perusakan alam juga banyak dipengaruhi oleh tangan manusia. Hal itu dipicu aktivitas manusia yang tidak ramah lingkungan. Penambangan kapur terjadi di hampir semua wilayah pegunungan kapur. Pengeboran, memasang paku dan pasak ditebingtebing, dan lain sebagainya merupakan cara manusia dalam proses pemanfaatan bumi yang berlebih.
Semua kegiatan manusia tersebut bertentangan dengan aturan dan norma adat daerah. Gambaran pemanfaatan bumi yang berlebih dapat dilihat dalam kutipan berikut.

\section{Ya. Kawasan Karst Citatah makin hancur oleh penambangan kapur." Ia menerawang ke perbukitan sekitar seperti mencemaskan hal yang sama di tempat ini."Karena itu kami ingin cepat-cepat meneliti daerah Sewugunung- Watugunung ini. Sebelum ia juga hancur seperti Citatah. \\ (BF/KI/KEE/Utami, 2019: 60)}

Parang Jati merasa harus segera melakukan penelitian di SewugunungWatugunung demi menjaga kelestariannya. Dia tidak ingin tempat kelahirannya hancur seperti yang terjadi di kawasan Karst Citatah. Kehancuran kawasan Karst Citatah disebabkan oleh kelompok pemanjat, kelompok penambang, dan aktivitas masyarakat setempat yang kurang bertanggung jawab. Penambangan yang dilakukan dengan bantuan teknologi mempercepat kehancuran kawasan gunung.

Pada sisi yang lain, pihak yang seharusnya merawat keindahan Sewugunung juga melakukan aktivitas yang kurang tepat. Mereka adalah kelompok birokrat. Atas nama pemanfaatan sarana pariwisata, mereka telah melukai pegunungan. Gambaran cerita tersebut dilihat dalam kutipan berikut.

Kalau kita mengebor dan memaku, kenapa tidak membuat tangga sekalian, dan memasang hiasan, patung dan lampu, seperti yang dilakukan para 
birokrat pariwisata terhadap goa-goa dan kawah-kawah sehingga hilang alamiahnya? Kalau kita merusak tebing, apa pula lebihnya kita dari serdadu? (BF/KI/KEE/Utami, 2019: 83)

Kian hari kian banyak manusia menghabiskan aset yang ada di alam secara habis-habisan dengan kecerdasannya. Melalui pernyataan di atas, Parang Jati menyampaikan pesan agar manusia dapat hidup berdampingan dan berdialog dengan alam. Sikap manusia yang menganggap wajar terhadap pengeboran merupakan dampak dari modernisme. Hal ini menandakan bahwa dengan adanya era modernisasi, manusia makin berani berperilaku yang justru makin menambah perusakan lingkungan.

Penggunaan alat-alat modern dapat merusak alam demi sebuah alasan yang kurang tepat. Dengan dalih memperindah tempat wisata, para birokrat berani membelah gunung, mengebor gua-gua menjadi tempat wisata. Para pelaku wisata berpendapat bahwa alam adalah tempat yang telah menyediakan seluruh kebutuhan manusia, sehingga tidak salah jika mereka memanfaatkan kekayaan secara maksimal. Hal ini dipengaruhi oleh pandangan antroposentrisme, bahwa manusia sebagai pengendali lingkungan. Manusia memiliki kebebasan dalam memanfaatkan seluruh potensi alam yang ada disekitar lingkungan. Cara pandang inilah yang menyebabkan manusia menguras dan mengeksploitasi alam demi pemenuhan kepentingan manusia tanpa memperhatikan kelestarian alam. Fenomena demikian juga sama dengan hasil kajian terhadap novel Anak-Anak Pangaro Karya Nun Urnoto ElBanbary oleh Sufyanto (2018) yang menyatakan bahwa perilaku konsumerisme dan industrialisme akan berdampak terhadap rusaknya lingkungan fisik maupun lingkungan biologis bahkan lingkungan sosial.

\section{PENUTUP}

Gambaran interaksi manusia dan lingkungan dalam novel Bilangan $F u$ karya Ayu Utami tercirikan sebagai berikut: adanya pencemaran udara, perusakan hutan, pemunculan tanda bencana, perusakan habitat, pemburuan binatang, dan eksploitasi bumi. Pencemaran udara disebabkan oleh asap kendaraan bermotor. Perusakan hutan disebabkan oleh kebakaran dan penebangan secara liar oleh masyarakat setempat dan para oknum militer. Pemunculan tanda bencana berasal dari ikan Pelus dan tidak semua masyarakat mampu mendapatkannya. Perusakan habitat akibat ulah masyarakat. Pemburuan binatang secara liar dan ilegal untuk dikonsumsi dan kesenangan semata. Eksploitasi bumi dilakukan dengan berbagai alat tanpa memikirkan dampak negatif yang akan terjadi demi ekonomi semata.

Setelah membaca novel Bilangan $F u$, pembaca diharapkan lebih peduli dan memiliki wawasan mengenai lingkungan. Wawasan yang dimiliki digunakan sebagai alternatif dasar pertimbangan pengelolaan lingkungan agar manusia tidak merugi.

\section{DAFTAR PUSTAKA}

Endraswara, S. (2016). Ekokritik Sastra Konsep, Teori, dan Terapan. Yogyakarta: Morfalingua.

$\begin{array}{rr}\text { Fajriah, I. A. (2018). } & \text { Corak } \\ \text { Teosentrisme } & \text { dan } \\ \text { Antroposentrisme } & \text { Dalam } \\ \text { Pemahaman Tauhid di } & \text { Pondok }\end{array}$


Pesantren Attauhidiyah Cikura Bojong Kabupaten Tegal (Skripsi). Semarang: Universitas Islam Negeri Walisongo.

Garrard, G. (2004). Ecocriticism. New York: Routledge.

Hananto, A. (2019). Tiongkok Berencana Luncurkan Bulan Tiruan ke Angkasa. Diakses pada 25 Nopember 2020, 19:44 WIB. https://www.mongabay.co.id/201 9/03/14/tiongkok-berencanaluncurkan-bulan-tiruan-keangkasa-apa-dampaknya-bagilingkungan/

Irwan, Z. D. (2018). Prinsip-prinsip Ekologi. Jakarta: Sinar Grafika Offset.

Juanda. (2018). Fenomena Eksploitasi Lingkungan Dalam Cerpen Koran Minggu Indonesia Pendekatan Ekokritik. Naskah diterbitkan: 31 Desember 2018, DOI:doi.org/10.21009/AKSIS.02 0203. Diakses pada 30 Nopember 2020.

http://journal.unj.ac.id/unj/index. php/aksis/article/view/9546/6354

Keraf, A. S. (2010). Etika Lingkungan Hidup. Jakarta: Buku Kompas.

Nugraha, D. \& Suyitno. (2019). On The Beginning of Modern Indonesian Literature. Humanities \& Social Sciences Reviews, 7(6). 604-616.

Nugraha, D. \& Suyitno. (2021). Kritik dan Penelitian sastra. Surakarta: Muhammadiyah University Press.

Nurkamilah, C. (2018). Etika Lingkungan dan
Implementasinya dalam Pemeliharaan Lingkungan Alam pada Masyarakat Kampung Naga. Religious: Jurnal Studi Agama-agamadan Lintas Budaya. 2 (2). 136-148.

Sekretariat Negara Republik Indonesia. (2009). Undang-Undang Nomor 32, tahun 2009, tentang Perlindungan dan Pengelolaan Lingkungan Hidup.

Sufyanto, H. (2018) “Ekokritik dalam Novel Anak-Anak Pangaro Karya Nun Urnoto El-Banbary". (Skripsi). Malang: Universitas Muhammadiyah Malang.

Tanjung, C. A. (2020). BBKSDA Riau Temukan Illegal Logging di Kampar, 6 Pondok Pelaku dibakar. Diakses pada Senin, 15 Juni 2020. 20:31 Wib. https://news.detik.com/berita/d5054813/bbksda-riau-temukanillegal-logging-di-kampar-6pondok-pelaku-dibakar/1

Utami, A. (2018). Bilangan Fu. Jakarta: PT Gramedia.

Wismabrata, M. H. (2020). Fakta Terkini Banjir dan Longsor di Garust Bupati Sebut Soal Kerusakan Hutan. Kompas.Com. diakses pada 25 November 2020 , 20:14 WIB. https://regional.kompas.com/rea d/2020/10/12/16120011/faktaterkini-banjir-dan-longsor-digarut-bupati-sebut-soalkerusakan-hutan?page=2.

Yahya, A. N. (2021). Teka-Teki Penyebab Banjir Besar di Kalimantan Selatan. Kompas.com. Diakses pada 29 
Januari 2021. 08.55 WIB. https://nasional.kompas.com/rea d/2021/01/21/08535951/tekateki-penyebab-banjir-besar-dikalimantan-selatan?page $=$ all

Yuono, Y. R. (2019). Melawan Etika Lingkungan
Antroposentris
Melalui Interpretasi Teologi Penciptaan Sebagai Landasan Bagi Pengelolaan-Pelestarian Lingkungan. Jurnal Fidei. 2 (1). 183-203. 